\title{
Seeing the world through the eyes of God: Reading the Book of Qoheleth in the light of Genesis 1:1-2:4a
}

\begin{tabular}{|c|c|}
\hline $\begin{array}{l}\text { Authors: } \\
\text { Gilbert N. Ala } \\
\text { Lawrence N. }\end{array}$ & $\begin{array}{l}\text { ibe }^{1,2} \text { (D) } \\
\text { kwuosa }^{2,3} \text { (D) }\end{array}$ \\
\hline $\begin{array}{l}\text { Affiliations: } \\
{ }^{1} \text { Department } \\
\text { Cultural Studi } \\
\text { Arts, Alvan Ikc } \\
\text { College of Ed } \\
\text { Owerri, Niger }\end{array}$ & $\begin{array}{l}\text { feligion and } \\
\text { s, Faculty of } \\
\text { ku Federal } \\
\text { cation, } \\
\text { a }\end{array}$ \\
\hline $\begin{array}{l}{ }^{2} \text { Department } \\
\text { Cultural Studi } \\
\text { Social Science } \\
\text { of Nigeria, Ns }\end{array}$ & $\begin{array}{l}\text { f Religion and } \\
\text { s, Faculty of } \\
\text { s University } \\
\text { ıka, Nigeria }\end{array}$ \\
\hline $\begin{array}{l}{ }^{3} \text { Department } \\
\text { Testament an } \\
\text { Scriptures, Fa } \\
\text { Theology and } \\
\text { University of } \\
\text { Pretoria, Sout }\end{array}$ & $\begin{array}{l}\text { Old } \\
\text { Hebrew } \\
\text { Religion, } \\
\text { retoria, } \\
\text { Africa }\end{array}$ \\
\hline $\begin{array}{l}\text { Correspondin } \\
\text { Lawrence N. } \\
\text { lawrence.okw } \\
\text { edu.ng }\end{array}$ & $\begin{array}{l}\text { g author: } \\
\text { kwuosa, } \\
\text { uosa@unn. }\end{array}$ \\
\hline $\begin{array}{l}\text { Dates: } \\
\text { Received: } 06 \\
\text { Accepted: } 01 \\
\text { Published: } 09\end{array}$ & $\begin{array}{l}\text { Apr. } 2021 \\
\text { uly } 2021 \\
\text { Sept. } 2021\end{array}$ \\
\hline $\begin{array}{l}\text { How to cite th } \\
\text { Alaribe, G.N. } \\
\text { L.N., 2021, 'Se } \\
\text { through the e } \\
\text { Reading the B } \\
\text { Qoheleth in th } \\
\text { Genesis 1:1-2 } \\
\text { et Ecclesia } 42 \\
\text { https://doi.or } \\
\text { ve.v42i1.2261 }\end{array}$ & $\begin{array}{l}\text { is article: } \\
\text { Okwuosa, } \\
\text { eing the world } \\
\text { jes of God: } \\
\text { ook of } \\
\text { e light of } \\
\text { :4a', Verbum } \\
\text { 1), a2261. } \\
/ 10.4102 \text { / }\end{array}$ \\
\hline $\begin{array}{l}\text { Copyright: } \\
\text { C 2021. The A } \\
\text { Licensee: AOS } \\
\text { is licensed unc } \\
\text { Creative Comr } \\
\text { Attribution Lic }\end{array}$ & $\begin{array}{l}\text { uthors. } \\
\text { IS. This work } \\
\text { ler the } \\
\text { nons } \\
\text { ense. }\end{array}$ \\
\hline Read online: & \\
\hline 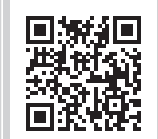 & $\begin{array}{l}\text { Scan this QR } \\
\text { code with your } \\
\text { smart phone or } \\
\text { mobile device } \\
\text { to read online. }\end{array}$ \\
\hline
\end{tabular}

Religious and existential concerns interweave in many books of the Bible to give attention to human's existential anguish, the sense of guilt, the horror of death, the atrocious experience of the absurd. While many contemporary existentialist philosophers prefer to do without God in the attempt to deal with human's existential contradictions, the search takes the authors of the Bible through intense spiritual struggles as they attempt to confront the belief in the goodness of God with the human experience of futility in all its facets. We want to seek a meeting point between the existentialist concerns of the book of Qoholeth with the profound theology of meaningfulness as elaborated in Genesis 1:1-2:4a. Our article therefore, has a decidedly pastoral orientation. We will attempt to move, through an analysis of select texts, to a re-affirmation of one of the spiritual truths that many mystics have tried to teach: that reason alone is not enough to guide the human person to the mysteries of life, the believer has to learn to unite with God or to the realities themselves to discover the fundamental goodness in many of the experiences that, in human perspectives, seem to be absurd.

Intradisciplinary and/or interdisciplinary implications: We believe such union is needed in a world where racism, violence to minorities, gender inequalities, homophobic attitudes are thickening the clouds of discrimination and threatening some to doubt the fundamental goodness of creation as made by God.

Keywords: creation; meaning; futility; human life; modernity.

\section{Introduction}

The first two chapters of Genesis and the last two chapters of Revelation delve with the theme of creation. While Genesis 1:1 begins with the pregnant clause: 'In the beginning God created heaven and earth'; Revelation 21 states:

Then I saw a new heaven and a new earth; the first heaven and the first earth had disappeared now, and there was no longer any sea. I saw the holy city, the new Jerusalem, coming down out of heaven from God, prepared as a bride dressed for her husband. Then I heard a loud voice call from the throne, 'Look, here God lives among human beings. He will make his home among them; they will be his people, and he will be their God, God-with-them. He will wipe away all tears from their eyes; there will be no more death, and no more mourning or sadness or pain. The world of the past has gone.... I am making the whole of creation new. (vv. 1-5)

The two passages from Genesis (the first book in the Bible) and Revelation (the last book in the Christian Bible) are very insightful, dealing as they do with the primal acts (creation) and the last things (eschatology). It is evident then that the creative act is not something that happened once, and then ceased to exist. But that even in the final acts of world history, a new creation will renew heaven and earth. Evidently, the belief of the Church in Life Everlasting has here a fundamental support. When all things are made anew, there will be no more grief and pain, every tear shall be wiped away, and God will dwell in the midst of his people. Then a new life will begin, freed from the contaminations that envelop the present existence, and the mortality that is the mark of our present experience.

When we read the Bible from these two axes, it could be seen that all that comes in-between, all the stories of warfare and catastrophe, of sin and death, but also of grace and divine encounters - all these are the stories of a world moving towards consummation in a renewed heaven and earth. As a result, the theology of creation is a theology of meaningfulness: 'Creation ... means that we are something instead of nothing, with all the possibilities of life and growth and happiness instead of the mere blankness of nonentity' (Sheed 1958:53). 
Perhaps such a theology of meaningfulness must be spoken out louder in the present climate of our faltering civilisation. Any attentive listener is all too easily aware of the overwhelming problems plaguing our jet age. Our world of action and social life is fragmented, filled with disorder, alienation and sterile conflicts. There are many levels of our experience of the chaotic human life - threatening us, sometimes splitting us apart, and always a formidable foe to contend with. Human beings are daily confronted with the existential threat of falling into chaos and nothingness. There is a sense of dissolution in human relations with respect to authority, family structures, education, friendship, sex, etc. touching places where our lives really vibrate. The social cohesion is in a state of creative chaos, with a never ending thirst for the redeeming grace. Radical changes are taking place in human's physical and spiritual climates, in their finer sensibilities, in their order of needs, values and objectives. And then there are all the limitations of our finitude: death, suffering, doubt, meaninglessness, temptation, and despair. These situations - and there are many others - strengthen the intuition that human life is surrounded by a formless expanse - without structure or consistency, amorphous. Much is indeed askew in our world today, giving rise to new anxieties. Perhaps the contemporary human person is in a better position to understand the existential struggles of the author of the book of Qoholeth as he labels all reality futile:

Vanity of vanities, says Qoheleth, vanity of vanities! All things are vanity! ... I have seen all things that are done under the sun, and behold, all is vanity and a chase after wind. $(1: 2,14)$

The meaningfulness of human life is not always a given, and often every human being must struggle to discover the meaning in his or her life's experiences. For this struggle to be able to terminate in a positive outcome, every Christian must be ready for a sort of mental iconoclasm - a shattering of the mental templates for organising and categorising the things in the world around us.

\section{Reality from the perspective of God: The fundamental goodness of creation in Genesis 1:1-2:4a}

Guillaume (2009:33) thinks that Genesis 1:1-2:4a constitutes an introduction to the entire Priestly corpus in the Pentateuch. The passage equally presents the main themes of the priestly narrative in a nutshell. We want to present the activities of God in the seven days of creation in Table 1 for clearer analysis.

\begin{tabular}{|c|c|c|c|}
\hline Day 1 & $\begin{array}{l}\text { Creation of light and } \\
\text { limitation of darkness } \\
(1: 4-5)\end{array}$ & Day 4 & $\begin{array}{l}\text { Luminaries created: sun, } \\
\text { moon, stars (1:14-19) }\end{array}$ \\
\hline Day 2 & $\begin{array}{l}\text { Creation of sky (heavens) } \\
\text { by separation of the } \\
\text { waters }(1: 6-9)\end{array}$ & Day 5 & $\begin{array}{l}\text { Birds and sea creatures } \\
\text { created (1:20-23) }\end{array}$ \\
\hline Day 3 & $\begin{array}{l}\text { Creation of dry land by } \\
\text { limiting sea; creation of } \\
\text { vegetation }(1: 10-13)\end{array}$ & Day 6 & $\begin{array}{l}\text { Domesticated animals, insects, } \\
\text { wild animals created; human } \\
\text { person created in the image } \\
\text { of God (1:24- } 27)\end{array}$ \\
\hline Day 7 & \multicolumn{3}{|c|}{ God rests from his creative work and sanctifies creation (2:1-4a) } \\
\hline
\end{tabular}

As Löning and Zenger (2000:105ff.) point out, a clear structure can be perceived in the form and content of the seven days. The first day, the fourth day and the seventh day of creation are distinctive in this structuring as they revolve around the theme of time as a basic category of the order in life. Although human beings are last to be created and important to creation, it is the Sabbath with which God crowns the creation which he beholds as 'very good' (Mertens 1987:85). In fact, the refrain, 'And God saw how good it was' occurs on the first day of creation with a little modification (Gn 1:4) and at the end when God looked at everything he had made, and he found it very good' (Gn 1:31). For Guillaume (2009):

Like humanity, the Sabbath is blessed. Unlike humanity, or all other creatures, the Sabbath is also sanctified (2:3). As the only creature to be blessed and sanctified, the Sabbath is the foundation of time and the measure thereof. (p. 45)

The fundamental goodness of creation is asserted in the Bible before the story of the origin of evil in Genesis 2-4 and as a result, even when our human experience of evil would seem to drive us towards the same pessimistic assessment as the author of Qoheleth, every man or woman must struggle to reaffirm the belief in the fundamental goodness of creation as highlighted and emphasised by Genesis 1:1-2:4a in Löning and Zenger (2000):

Creation theology recalls the creation of the world and of human beings 'as a beginning' and indeed 'from the beginning; as a good, beneficial, and indestructible life-context with God as the creator and king of 'his' world. (p. 9)

The good beginnings of the world often contrasted, in the biblical times, with the harsh socio-cultural and historical realities that Israel often faced. It seems Qoheleth was a reflection of this chaotic human experience especially when the book of Qoheleth reflects the first of Genesis two creation accounts. According to Day (n.d.) Qoheleth's use of this material is quite possible. The consideration is based on the fact that Genesis 2:4b-3:24 is considered part of the Yahwist tradition and dated to the 10th or 9th centuries, and Genesis 1:1-2:4a, which is Priestly, is dated pre-exilic or exilic. Since the vocabulary of the book of Qoheleth places it late, no earlier than the Persian period, its author(s) could quite likely have been familiar with this earlier material in some form. In Qoheleth is found some of the thoughts and imageries in the creation accounts like a generic view of God than a deity with specific characteristics (1:13); life which is the gist of creation comes alive in it despite all the talks about death (9:4). The location of action is the earth with attention paid to the questions of newness, time and eternity in creation terms like sun, light, moon, rain, trees and breath used (cf. 1:10-11; 2:16; 3:11, 14-15; $4: 16 ; 6: 6,10-12 ; 7: 8-10 ; 10: 14)$.

Genesis gives foundation to Qoheleth's discourse in the sense that Qohelet did not just set out to discover the meaning of life. His endeavour was more of finding what is good for human beings to do during their short lives. This is a continuation of the task established for humans in their quest to master the knowledge of good and evil. Again, the rejection of retribution 
by the author and his method of discovering what is good shows his Genesis background. He went further to conclude that the world cannot be changed and that humans can only make the most of the world as it is (Moxham 2015).

For this and other reasons, Löning and Zenger (2000) insist that the creation theology can adequately be utilised as a response to chaotic experiences of human life. With its invocation of the good beginning, it can be used to overcome and fend off existential anxiety and threats to life. This is why we feel it makes for a better reading of the book of Qoheleth, when we begin to read it within the context of Genesis 1:1-2:4a because it seems, as Hertzberg (1963) states, that Qohelet appears to have had Genesis 13 open before him as he wrote. And if this is so, then God's good creation that was cursed in Genesis 3 is still capable of being beautiful for in it, God's purposes for human beings are achieved. Consequently, in Qoheleth understanding, a curse world could still be described as good (Moxham 2015).

\section{Reality from human perspective: Futility of human experience in the Book of Qoheleth}

Kreeft (1989:15) calls Ecclesiastes 'a book about meaninglessness', and notes that the book presents an alternative viewpoint to the rest of the Bible. It is the only book in the Bible where God is completely silent. There is no appeal to any divine revelation in the book, and in a sense the book presents to us the picture of what life is all about when God does not himself reveal to us what life is. Kreeft (1989) goes further to say that:

Unlike all the other books of the Bible, it has no faith flashbulb attached to its camera to reveal the inner depths or hidden meanings of life. It uses only the available light 'under the sun': sense observation and human reason. The surface of life appears in this book with total clarity, brutal honesty, and spiritual poverty. Ecclesiastes is the truest picture of the surface that has ever been written. (p. 19)

So, Ecclesiastes is first a book about human existence, rather than a book presenting a theology of divine revelation (Walsh 2012). For Enns (2008:121), it is at odds with theological trajectories evident elsewhere in the Hebrew scriptures. This unique nature forces scholars such as Scott (1982:191-193) to concede Ecclesiastes as the strangest book in the Bible, and question the criteria for its admittance in the canons of Judaism and Christianity because it stands alone in almost every respect. In the same vein, Waltke (2007) asserts that, 'The book of Ecclesiastes is the black sheep of the canon of biblical books. It is the delight of skeptics and the despair of saints' (p. 946). The book concentrates on human reality which is very complex, especially when there is no place for God. It tends to show that life without God is empty and vain as it concerns pleasure $(2: 1-3,10)$, hard work and achievements (2:4-11), wisdom (2:12-16), labour (2:17-23; 4:4), self-deprivation (4:7-8), human craving for wealth $(5: 10-13 ; 6: 2)$, human pitiful exit $(6: 2-3)$ and the irreconcilable manner in which the righteous and the wicked are rewarded (7:15; 8:14-15).
Looking at the canon of biblical books, the only book that can be compared with Ecclesiastes is the book of Proverbs. Baylis (1996) notes the tensions and touching points between both books:

The book of Ecclesiastes is the other side of the coin from the book of Proverbs ... Proverbs is positive, whereas Ecclesiastes has a pessimistic tone to it. Proverbs tells us that wise living, righteousness, and diligence all work. Ecclesiastes points out that all too frequently they don't work. There is a futility and frustration to life as we view it on the earthly level. ... Proverbs and Ecclesiastes do not really contradict. Just as Proverbs really knows that things do not always go well, Qohelet would tell us that we can't expect to make sense of everything as if this were a perfect, unfallen world. Yet there are things to enjoy as we live a life moderated by the knowledge of future judgment and directed by the fear of Yahweh and his commands (11:7-9; 12:13-14). In the end, Ecclesiastes corrects an improper reading of Proverbs. We are to practice justice, diligence, loyalty, and integrity because they are right, not because they always profit or always work out for our benefit. (p. 260)

However, the intention here is to counterbalance the pessimism of Ecclesiastes with the positive spirit of Genesis 1:1-2:4a. In this case, Genesis 1 shares similarities with the book of Proverbs as a counterweight to Qohelet. If Genesis 1:1-2:4a gives us the picture of reality as created and seen from the perspective of God, and independent of any deduction from human experiences, the book of Qoheleth presents us with a summary of reality as experienced by humans. The argument of the book is summarised in the first three verses:

The words of the Preacher, son of David, king in Jerusalem. Vanity of vanities, says the Preacher, Vanity of vanities! All is vanity. What does a man gain by all the toil at which he toils under the sun? (Gn 1:1-3)

Scholars have noted the close connection in the meaning of the two root metaphors in both texts: tohuwabohu in Genesis 1:1-2:4a and hebel in Qoheleth. Ordinarily, the Hebrew word hebel means breath, vapour, smoke, wind, air and the like (Onwukeme 2012). The Greek Bible (Septuargint) translates it with mataiotes (worthlessness, futility), while the Latin Bible (Vulgate) renders it in Latin with vanitas (vanity). Figuratively the word hebel, as used in the book, can denote transience and insubstantiality, emptiness and futility. It is the favourite word used by the author of the book. He used it 38 times out of the 73 occurrences in the entire Hebrew Bible (Reed 2012) to qualify whatever is irritable or frustrating to him: such things include the sudden disappearance of a great achievement in life (2:11); the ultimate levelling of all life in death (3:19); the unhappy lot of various people (4:8); the insatiable desire of the human heart (5:10); the inequities of the divine scheme of things (6:2); the laughter of fools (7:6); the injustices to which people are subjected (8:14), and so forth.

The Preacher pronounces all human toil vanity. Thereby, he highlights five features of the world and of human life that make everything 'under the sun' to be labelled as vanity (Kreeft 1989:45):

- The sameness and indifference of all things. 
- Death as the certain and final end of life.

- Time as a cycle of endless repetition.

- Evil as the perennial and unsolvable problem.

- God as an unknowable mystery.

More specifically, the author makes a study of five of our human attempts to find meaning in life (see Table 2). Each 'toil' lacks the 'gain' we seek from it (Kreeft 1989:36-38).

Qoheleth qualifies all human activity as hebel: the accumulation of goods which are turned over to someone else (2:26), a person's envy of other's possession (4:4; 6:9), etc. The sense of the word in these usages is that human pursuits are aimless and futile, and there is no ultimate gain or advantage in any human toil or achievement. This is because chance events can all too easily undermine a person's accomplishments at any moment, and eventually death will cancel out all of human achievements. The verdict of uselessness pronounced on all of human toil inclines the author to a pessimistic outlook on all of life. The pessimism extends to the sad treadmill in human society $(4: 8 ; 6: 7)$, as well as in the incessant routines of natural cycles (3:1-15). Nowhere does the author discover absolute meaningfulness. All that is left to human beings is relative meanings that can be constructed and reconstructed - and in the end we are left with vanity again. Some of the perplexities of life faced by Qoheleth as vanities of life are:

1. The limitedness of wisdom. The author of Qoheleth severally professes his admiration for wisdom. It is clear in his use of it to examine all that is done under the sun (1:13). Wisdom was more advantageous than folly (2:13); God takes no pleasure in fools (5:4); wisdom leads to worldly success (7:19), life and progress (10:10); wisdom is greater than power (9:15) and better than weapons of war (9:18). Qoheleth expects human wisdom to provide certainties about life, but is left frustrated that human wisdom cannot master the secrets of the universe. Wisdom was beyond his grasp (7:23-24). And not even after weighing up many proverbs (12:9) was the road to wisdom opened to him. There still remained many unanswered questions in life, with which the person of faith must live.

2. Lack of benefit in human labour. From the outset, Qoheleth's poses the question: 'What does a man gain from his toil?' $(1: 3 ; 3: 9)$. It is clear that the search is not for the meaning of life but an inquiry into the benefits of labour in a context in which everything is transient. After one's investment of time and effort in being wise, Ecclesiastes evaluates whether there is any advantage to

TABLE 2: Perplexities of life.

\begin{tabular}{ll}
\hline Toil & Means to it \\
\hline Wisdom & Philosophy to fill your mind \\
Pleasure & Hedonism to fill your body \\
Wealth and power & Materialism to fill your pocket \\
Duty, altruism, social service, or honour & Ethics to fill your conscience \\
Piety, religion & Religion to fill your spirit \\
\hline
\end{tabular}

Source: Adapted from Kreeft, P., 1989, Three philosophies of life. Ecclesiastes: Life as vanity; Job: Life as suffering; Song of Songs: Life as love, Ignatius Press, San Francisco, CA. the labour involved. The emphasis in Ecclesiastes is not about human meaning; it is about labour's benefit (Fredericks 2010). The author goes ahead to survey the results gained from several activities of humans, using the person of Solomon as benchmark. Solomon, the famous King of Israel, who did experience life to the full (2:10) had enough of houses, vineyards, gardens, orchards, flocks, slaves, wives and concubines (2:4-8), and yet he was aware that none of these will survive him (2:18-23). This was a cause for frustration (Onwukeme 2012). So, whatever human beings labour to gain would come to naught at their death and are thereby rendered meaningless (9:6). This is a cause for frustration, and strengthen the intuition of the author of Qoheleth that all human toil is futile.

3. No justice in human life. The arbitrariness that Qoheleth observes in places where justice should prevail, lead him to conclude that earthly justice cannot guarantee true happiness. According to Onwukeme (2012), Qoheleth is quite blunt in his presentation of the complexities of divine justice and retribution in life situations: sometimes corruption and evil are found in places where justice and righteous ought to be found (3:16); often those trapped by injustice die without seeing God's vindication (7:15; 8:14); God often dismays us by his ways (3:11), and human beings must resign themselves to accepting sorrows and joys that God sends (7:14). It is the inability of human beings to discern the works of God especially His justice in the world which is not working (9:1-2) and a mystery (Whybray 1989) that turns everything into vanity.

4. Lack of meaning in pleasure and religion. In 2:1-11, the author lists a number of amusements he had taken to make himself happy. But neither laughter, nor mirth nor wine, could give him meaningful joy in the limited days of his life. All was vanity and a chase after wind (2:11). The Preacher thus looks up to God believing that only God is big enough to satisfy human's heart: 'I recognized that whatever God does will endure forever; there is no adding to it, or taking from it' (3:14). But then, God is in heaven, and human beings are here on earth (5:1). And so, knowledge of God's ways escapes the grasp of humans - even the grasp of religion. The author ridicules the presumptuous faith, and the triumphalist religion $(4: 17-5: 6)$. Religious practices are futile as ends in themselves, without being accompanied by the fear of God. Reverence and fear of God are preferable than empty words and haughty attitudes while making sacrifices, vows and prayers (Onwukeme 2012).

\section{Discovering meaning in reality: Looking at the world through God's eyes}

It is in light of the above reading of the book of Qoheleth that we think the image of creation's fundamental goodness should be a root metaphor for faith and spirituality. Root metaphors are important imageries that help us to anchor our sometimes, haphazard efforts at finding meaning in life. 
According to Samuel (1996), they help us to reflect the basic primal and mythic questions every people and civilization has asked since the beginning of time dealing with the nature and mystery of human existence - for example, 'Why are we alive?' 'What is the nature of good and evil?' 'Why do we suffer?' 'What happens to us after we die?' 'What is God like?' 'Is the universe a friendly or chaotic place?' They express humanity's deepest existential concerns and touch upon issues that matter most in a person's lives. They shape the way we view and experience the world. They awaken our consciousness.

A root metaphor colours our outlook, our perspective towards the world. We are suggesting the theological message of Genesis 1:1-2:4a attesting to the fundamental goodness of creation as a primal image of faith. The idea that all things are fundamentally good in the eyes of God is an important lesson of mysticism. One of the great theologians of the Church, Rahner (1981), has rightly said that the contemporary Christian must either be a mystic or no Christian at all. The saying does not mean that every Christian must become a contemplative. It rather suggests that every Christian must learn to assess experiences and encounter persons as they are 'in God' rather than as they are perceived by human beings. Our greatest treasures, the world's purest gold, may turn out to be only vanity - without God. This is the point made also by St. Paul in Philippians 3:2-11, when he claims that his life without Christ would still be a loss, even when he adds all his worldly successes, education, wealth, power, prestige, and privileges.

Our contemporary world is bedevilled by all sorts of conflicts, and torn apart by divisions within and without. Our contemporary society is heated up by such issues as racism, gender inequality, discriminations resulting from ideological, sexual, economic or geopolitical differences. Part of the reasons for all these divisions is that we have learnt to view events and experiences from the surface (Girzone 2009):

Ordinary people live on the surface of life, viewing events and people in very limited ways, usually according to how people and events affect themselves and their families, or how they affect their business or other interests in their daily life. Most other people or happenings in the world mean little or nothing to them, because they have no real effect on their lives. Of all the dramas, both happy and tragic, that occur worldwide ordinary people have very little interest in knowing about, or if they do, their interest or desire to be more deeply aware is very limited, as these happenings are of little personal significance, or affect them in any way that they should be concerned. (par. 1-3)

While it is all too easy for us today to label 'difference' as absurd, and to try to stifle the fundamental goodness of creation as found in others, an appreciation of the mystical lessons of Genesis 1:1-2:4a can help us to see things not as they are in themselves, through the ordinary mode of human perception, in time, but as they are in eternity, as they were in God before all-time began and will be forever (Vouthon 2013). As Qoheleth intuits, so much of our experiences count for nothing in the light of the ultimate meaning, so much of our achievements fade and lose their relevance with time. And so, we must learn to see the world as God sees it, we must learn to 'breakthrough' time into the light of the first creation, to see ourselves and all things as they are in God before creation in time. St. Paul advices Christians in Romans 12:

Do not conform yourselves to this age but be transformed by the renewal of your mind, that you may discern what is the will of God, what is good and pleasing and perfect. (v. 2)

There are qualitative differences in the way God looks at life. God's perspective is far beyond the range of human understanding. In aiming to discern the will of God, the believer must be ready for a constant iconoclasm, a constant subverting and smashing of our preconceptions, narrowness, projections, and logical categories of human understanding, in such a way that out of the ruins comes a new invitation to live in a new wonder (Cordero 2005):

When we look at life through our own eyes, we only see what we are living at that moment. We get so absorbed by conditions around us that we let the conditions dictate our lives. We let conditions dictate our responses. When everything is going our way, we consider ourselves happy. On the other hand, when things are not going our way, we become discouraged, unhappy and depressed. We allow our circumstances to rule the way we feel. We see our problems as bigger than they actually are. God looks at life differently. Because God is eternal, he sees the past, present and the future all at the same time. God sees the end from the beginning. (par. 7)

How can we come to know something as it is in God, rather than as it is experienced by human beings? By learning from the Preacher to access events and experiences in the most lasting and profound ways. Only thus can events and experiences begin to lose their lustre in the light of eternity. Or they acquire added significance as the divine light shines on them. God has a more comprehensive view of reality. Given this, a proper Christian's attitude towards the Holy God is one of humility, of constantly backing off and giving God the space within which to be God. Because the eternal God sees the past, present and the future all at the same time, what today may look in our eyes as absurd and meaningless, may in God's farsightedness eventually lead to our good: 'For we know that all things work for good for those who love God, who are called according to his purpose' (Rm 8:28).

Every person has a perspective that permeates his or her interpretation of life and the world around him or her. Even when we share a common world with others, there still remains the world of our own, shaped uniquely by our perspective. How and what we bring to look at things greatly determines our ability to find meaning in life's many experiences. Perhaps we often allow our pains and aches to determine our 'point of view'. The profoundly Christian way - even when we sometimes experience our lives as threatened, and our world as capable of doing us harm - is to affirm, with Genesis 1:1-2:4a, the fundamental goodness of life and of the world. That is the easiest way we can embrace our life in the world and its many challenges with a 
positive outlook. Groome (1998:118-119) aptly notes how the ancient Greek thinkers created a branch of philosophy called cosmology (from the Greek cosmos meaning 'ordered universe'). Their intent was to look at the world and understand it from the underlying perspective that it makes sense and has patterns of meaning. Only when we learn to look at life from the perspective of God can we begin to see the world correctly.

Below we want to highlight key points about the mystical way as could be gleamed from a long tradition of Christian mystics: Meister Eckhart, Johannes Tauler, Henry Suso, Jakob Boehme, Jan Van Ruysbroeck and Angelus Silesius. They describe for us helpful ways of looking at the world and the many experiences that we make within it:

- To see through the eyes of God is to see humanity as God sees humanity: with unconditional love.

- In order to see with the eyes of God, we first have to see God. And when we understand how God sees us, we can look at our neighbour and fully understand what God sees in each and every one of us: a precious soul (cf. $1 \mathrm{Sm}$ 16:7).

- This world may appear cruel and harsh to our unenlightened eyes, but even the brutality and suffering seen in our imperfect world may have meaning of their own, a meaning beyond our human comprehension.

- In themselves, all things are accidental. In God, when viewed at their root, when penetrated to their core and seen as he eternally sees them, all things are God in God.

- The outer eye sees only the illusion, the inner eye sees the eternal reality of the thing - whether it be a flower, an animal or a person - as it is in God. Contemplation of the physical world, of existent things, is born from inner contemplation. Once a person has found that oneness with God at the core of his or her being, eye to eye with him, one is able to see the world as God sees it rather than as human beings do.

- And when we come to the crossroads where life looks to us as futile, we must look at what God says about life (it is good). Then we must look at what God says about the problem we may be going through. And finally, we must believe everything God says.

- To be able to appreciate the goodness in others, we need to break out of our narrow, self-contained, self-oriented worlds and get involved with the people around us.

For Paul, futility is built into creation as a result of its slavery to corruption. As a result of this, we often experience God's good creation as futile until, adopted into God and disposed to see creation as is seen by God himself, we are enabled to experience redemption ( $\mathrm{Rm} 8)$ :

I consider that the sufferings of this present time are as nothing compared with the glory to be revealed for us. For creation awaits with eager expectation the revelation of the children of God; for creation was made subject to futility, not of its own accord but because of the one who subjected it, in hope that creation itself would be set free from slavery to corruption and share in the glorious freedom of the children of God. We know that all creation is groaning in labour pains even until now; and not only that, but we ourselves, who have the first fruits of the spirit, we also groan within ourselves as we wait for adoption, the redemption of our bodies. (vv. 18-23)

\section{Evaluation}

Both texts we have considered - Ecclesiastes and Genesis 1:1-2:4a - can be seen to be so different in many ways. Ecclesiastes is the only book in the Bible in which God is completely silent; Genesis 1:1-2:4a is one text in the Bible where only the voice of God is heard in all of creation. Ecclesiastes asks the great questions of contemporary humanity: does my existence have any meaning whatsoever? How far can humans-without-God discover meaning and purpose in their life? Genesis 1:1-2:4a presumes the answers to these questions by affirming the fundamental goodness of creation. The author of Ecclesiastes attempts to find answers to basic existential questions in purely anthropocentric terms; Genesis 1:1-2:4a gives us the picture of the world from the perspective of God. Both texts can speak to many of our existential anxieties by their sheer honesty, by the audacity of their claims, and the profundity of their message. In our secularised contemporary society, where many no longer find the connection to the divine, both texts can engage our spiritual struggles and help to shape our existential responses. Even when Qoheleth describes everything else as futile, God escapes this description in the entire book. God's works do not fit into the category of 'a chase after the wind' (1:14). God's works endure. And to see things through the eyes of God, will be to be able to see things aright; and to be able to be preoccupied with the tasks God sets for humanity, is to be able to catch the tentative meanings that can be vouchsafed to humans. So, if, in Qoheleth's view, human wisdom is inadequate for understanding the ultimate meanings in human life, it is his insight that only the divine wisdom in humankind can get to the root of things. In a sense then, Qoholeth affirms the insights of Genesis 1:1-2:4a in a roundabout way.

\section{Acknowledgements Competing interests}

The authors declare that they have no financial or personal relationships that may have inappropriately influenced them in writing this article.

\section{Authors' contributions}

G.N.A. conceptualised the topic and it was discussed by both authors. Materials were gathered by both authors, while the G.N.A. put the initial draft together. L.N.O. reviewed the draft and made suggestions, which both authors discussed and applied where necessary.

\section{Ethical considerations}

This article followed all ethical standards for research without direct contact with human or animal subjects. 


\section{Funding information}

This research received no specific grant from any funding agency in the public, commercial or not-for-profit sectors.

\section{Data availability}

Data sharing is not applicable to this article as no new data were created or analysed in this study.

\section{Disclaimer}

The views and opinions expressed in this article are those of the authors and do not necessarily reflect the official policy or position of any affiliated agency of the authors.

\section{References}

Baylis, A.H., 1996, From creation to the cross: Understanding the first half of the Bible Zondervan, Grand Rapids, MI.

Cordero, R., 2005, Look at life through god's eyes, viewed, from http://articles.sunsentinel.com/2005-06-10/community/0506080279_1_god-eyes-time.

Day, L., n.d., Creation themes in Qoheleth, viewed 20 January 2020, from https:// oimts.files.wordpress.com/.

Enns, P., 2008, 'Ecclesiastes 1: Book of', in T. Longman III \& P. Enns (eds.), Dictionary of the Old Testament: Wisdom, poetry \& writings, pp. 121-132, Inter-Varsity Press, Nottingham.

Fredericks, D.C., 2010, “Ecclesiastes," in Ecclesiastes \& The Song of Songs', in D.W. Baker \& G.J. Wenham (eds.), Apollo's Old Testament Commentary, vol. 16, InterVarsity Press, Wenham, IL.
Girzone, J., 2009, A contemplative or a mystic views life through God's eyes, viewed 26 June 2014, from http://joshuamountain.org/postings/?p=4802.

Groome, T., 1998, Educating for life: A spiritual vision for every teacher and parent, Thomas More, Dallas, TX.

Guillaume, P., 2009, Land and calendar: The priestly document from Genesis 1 to Joshua 18, T \& T Clark, New York, NY.

Hertzberg, H., 1963, Der Prediger, Mohn, Gütersloh, p. 230, cited in Murphy, Ecclesiastes, p. xlii.

Kreeft, P., 1989, Three philosophies of life. Ecclesiastes: Life as vanity; Job: Life as suffering; Song of Songs: Life as love, Ignatius Press, San Francisco, CA.

Löning, K. \& Zenger, E., 2000, To begin with, God created ...: Biblical theologies of creation, transl. K. Omar, The Liturgical Press, Minnesota, MN.

Mertens, H.-E., 1987, 'The doctrine of creation in ecological perspective', Louvain Studies 12(1), 83-88. https://doi.org/10.2143/LS.12.1.2013989

Moxham, R., 2015, Qohelet's Fall: The use of Genesis 24 in the Book of Ecclesiastes, viewed 21 May 2020, from https://ourarchive.otago.ac.nz/.

Onwukeme, V., 2012, Searching for meaning with Qoheleth, Turners Printing, Longford.

Rahner, K., 1981, Theological Investigations: Concern for the Church, vol. 20, Darton, Longman \& Todd Ltd, London.

Reed, M.R., 2012, The politics of pessimism in Ecclesiastes, Society of Biblical Literature, Atlanta, GA.

Samuel, M., 1996, The lord is my Shepherd: The theology of a caring god, Jason Aronson Inc, London.

Scott, R.B.Y. (transl. \& ed.), 1982, The anchor Bible volume 18: Proverbs-Ecclesiastes, 2nd edn., reprint, Doubleday and Company, New York, NY.

Sheed, F.J., 1958, Theology for beginners, Sheed and Ward, London.

Vouthon, 2013, Two ways of seeing the world, according to the Christian mystics, viewed 25 May 2021, from https://www.religiousforums.com.

Walsh, C., 2012, 'Theological trace in Qoheleth', Biblical Theology Bulletin 42(1), 12-17. https://doi.org/10.1177/0146107911431224

Waltke, B.K., 2007, An Old Testament theology: An exegetical, canonical, and thematic approach, Zondervan, Grand Rapids, MI.

Whybray, R.N., 1989, Ecclesiastes, Old Testament guides, Sheffield Academic Press, Sheffield. 